\title{
"They Stepped on Their Toes". Reception of the Buffalo Bill's Wild West and Congress of Rough Riders of the World in Polish Press of Galicia, $1906^{1}$
}

\author{
Bartosz Hlebowicz \\ Independent researcher, Florence, Italy
}

\begin{abstract}
At the turn of the $20^{\text {th }}$ century many Native Americans took part in white man's enterprises: first Wild West shows, then silent movies. Wild West shows toured not only the United States but the Old World as well, including the south-eastern edges of the AustroHungarian Empire. Among the Native Americans who performed in Europe particularly visible were the Lakota (western Sioux) who performed, among others, in Buffalo Bill's Wild West show. The most famous of these Lakotas was Sitting Bull who had led his people's military resistance against encroaching white Americans a decade beforehand. Sitting Bull joined the Buffalo Bill's show for 1885 season. In 1890, the Sioux and other tribes lived a great religious awakening that was named Ghost Dance, hoping that by performing the Ghost Dance ritual they would make their lives better and get rid of the white men who took their lands, put them in reservations, broke treaty promises and brought hunger and diseases. On December 15, 1890, Sitting Bull was killed by Indian Police in front of his cabin at the Standing Rock reservation. Two weeks later, on December 29, 1890, at least two hundred, but perhaps as many as three hundred, Lakotas were killed in the tragic battle (that soon turned into a massacre) at Wounded Knee or died in its aftermath.

A few months later, almost one hundred Lakotas, including those who survived Wounded Knee massacre, joined the Buffalo Bill show during its second European tour. In 1902 they participated in the third European tour of Buffalo Bill's Wild West, now called Buffalo Bill's Wild West and Congress of Rough Riders of the World. I will discuss the show as well as the Native American performers and their reception while the show travelled among Polish cities during the summer of 1906, almost at the end of that tour. Delving into Polish press of that period, I will attempt to demonstrate how the Polish press made various, sometimes quite unexpected uses of the show.
\end{abstract}

Keywords: Buffalo Bill, entertainment, Indians in Europe, the Sioux, Wild West shows in Poland

1 I express my gratitude to Carl Masthay of St. Louis for his comments and revision of an earlier draft of the article. 
"Since the future of Native American culture at present seems dire, the sole possibility for the young brave bent on improving his social position is to appear in a Western movie", wrote ironically Umberto Eco in his instructions "How to Play Indians". To be a good 'movie Indian', "In any attack on a stagecoach, always follow the vehicle at a short distance or, better still, ride alongside it, to facilitate your being shot." When you attack a circle of covered wagons, "never narrow your circle, so that you and your companions can be picked off one by one". (ECo 1994:217-219).

Eco offers an explanation as to why Native Americans at the turn of the $20^{\text {th }}$ century so willingly joined the cinema industry and the show business at large, including the so-called Wild West shows, which chronologically appeared first. Apart from this, Eco laughs at the stereotypic figure of the 'Hollywood Indian warrior', perpetuated in so many films. I quoted just two of more than twenty 'instructions' describing how 'real Hollywood Indians' should behave. And when one reads descriptions of Wild West show performances of Buffalo Bill and other American showmen or about European circuses in which Native Americans performed, one has to admit that Eco was quite right in his observations. ${ }^{2}$ It is enough to recall the famous John Ford's The Stagecoach sequence with the Apaches attacking a wagon and doing strange things in order not to catch it and to lose as many warriors as possible. Yet, this is only one side of the story. Native Americans readily went with Wild West shows to Europe, for several reasons. ${ }^{3}$

Both in Wild West shows in America and in Europe they were exhibited along with elephants, camels, zebras, 'Cossacks', Ethiopians, and Bedouins, among other 'species'. During the1860s, circuses in Europe purchased elephants, giraffes, and hippopotamuses. At the turn of the century the circuses started shipping human beings from exotic places like Africa, Asia, and the Americas. They built villages in which tribes were exhibited and their inhabitants greeted the European tourists. "When our part in the show was over, we went to our village, where the visitors had a chance to see how we lived", wrote one of the Lakota performers in the Buffalo Bill's Wild West (STANDING BeAR 1928:255).

2 In many ways, silent movies were a continuation of the Wild West shows. In fact, as in the case of the famous Buffalo Bill's Wild West, and to a minor extent the Millers Brothers 101 Ranch, these forms sometimes overlapped. The show owners tried their luck in the film business as well as directors and sometimes actors (Buffalo Bill), and the Native Americans performed in both movies and Wild West shows: often the same Indians played in Wild West shows, other shows and movies directed on the 101 Ranch in northern Oklahoma, as well as movies run by the Bison Moving Picture Company in California. Wild West shows usually performed in the summer, which gave an opportunity for silent film producers (most notably William N. Selig of Chicago) to hire their actors, use their props, as well as their outdoor stunts like rope tricks, broncho or fancy riding in film plots (SмIтн 2003:60-61). Buffalo Bill himself, apart from having his actors perform in early Edison productions in 1894, tried to transfer his Wild West show formula into a film, though with little artistic success (Simmon 2003:62-63).

3 Henry M. Tidwell, superintendent at the Pine Ridge reservation, in a letter to a commissioner of Indian affairs, Charles H. Burke, complained that he struggled (evidently without much success) to keep Lakotas from performing at "every fair within a radius of one hundred miles of the Reservation" (quoted in Friesen - ChladiuK 2017:50). According to Ernest W. Jermark who replaced Burke as superintendent, between 150 and 200 professional Lakota performers were "willing to travel around the country for little or no salary, so long as traveling expenses and beef are provided" (FrIESEN Chladiuk 2017:51). And a perspective of travelling to Europe must have been just an extra stimulus. 


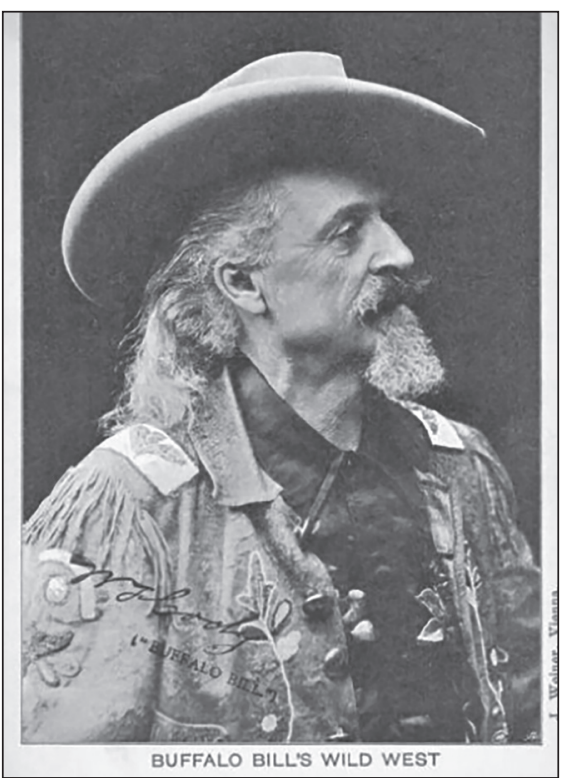

Figure 1. Buffalo Bill, photo taken in 1906, Vienna: J. Weiner, a postcard (National Library of Poland)
Often, the central message of the shows was the retreat of wild life in confrontation with the machine of Progress. Therefore, the Indians, even though they kept massacring $\mathrm{Custer}^{4}$ and his soldiers in Buffalo Bill's shows, were presented and perceived as things of the past, their style of life, and their warlike nature, belonging to bygone days. They faked attacks and/or massacres of the settler's cabins or the Boy General's unit, but Buffalo Bill always arrived to save the victims in these spectacles. If not, it was always clear that the spectators were offered representations of things of the past. The Indians represented exoticism and violence and at the same time they were harmless (KASsON 2001:191-195). Thus, Native Americans continually "vanished" all over America in traveling tours of Buffalo Bill and other entertainers. They - the Pawnees, the Comanches, the Poncas, the Iroquois, and most of all the Sioux - did this also overseas, traveling with Wild West shows to Europe and other continents until the 1930s.

In this article I am interested in the most famous of the Wild West shows, that of William Frederick Cody alias Buffalo Bill (Fig. 1). I focus on the role the Lakota (western Sioux) played in it. More specifically, I will discuss the reception of the show and of its Native American performers, while it travelled through Polish cities during the summer of 1906, on its last European tour. Delving into the Polish press of that period, I will attempt to demonstrate how the Polish press made various, sometimes quite unexpected uses of the show and its Native American performers.

4 Lieutenant Colonel, Brevet Major General George Armstrong Custer, called 'boy general' because of his relatively young age, was killed together with his entire battalion ( 210 men) during the Battle of the Little Bighorn (June 25, 1876) in Montana Territory, with the Sioux and the Northern Cheyenne tribes. This was one of the final acts of the Great Sioux War. Among the Indians there was no single leader who would direct the battle, instead many leaders and warriors led an effective counterattack against the American soldiers, for example Knife Chief (Oglala Sioux), Crow King (Hunkpapa), Hump (Minneconjou Sioux), Lame White Man (Cheyenne). The most famous were Crazy Horse (Oglala), Gall and Sitting Bull (both Hunkpapa) (Bray 2006:217-238; UtLey 1993:150-164). Paradoxically, Custer, who was an officer of no particular significance and no particular merits in fighting Indians (whereas he did distinguish himself during the Civil War a decade before), by leading his soldiers into defeat ensured himself eternal fame of a self-sacrificing hero, a martyrdom, and his "disastrous defeat was transformed into higher victory", as a historian Brian W. Dippie put it (1987:101). Custer became the most famous American officer and was mythologized in popular art, including numerous Wild West shows, as the premier Indian fighter. His defeat, which occurred precisely when the American nation was celebrating its centennial, angered the country authorities which, sending a third of the American army to curb the Indians in the Northern Plains, within a few months pushed most of the victors of the Little Bighorn into reservations (DiPPIE 1987:109-111, UTLEY 1993:291-307). 


\section{THE BEGINNINGS OF BUFFALO BILL'S DRAMA OF CIVILIZATION}

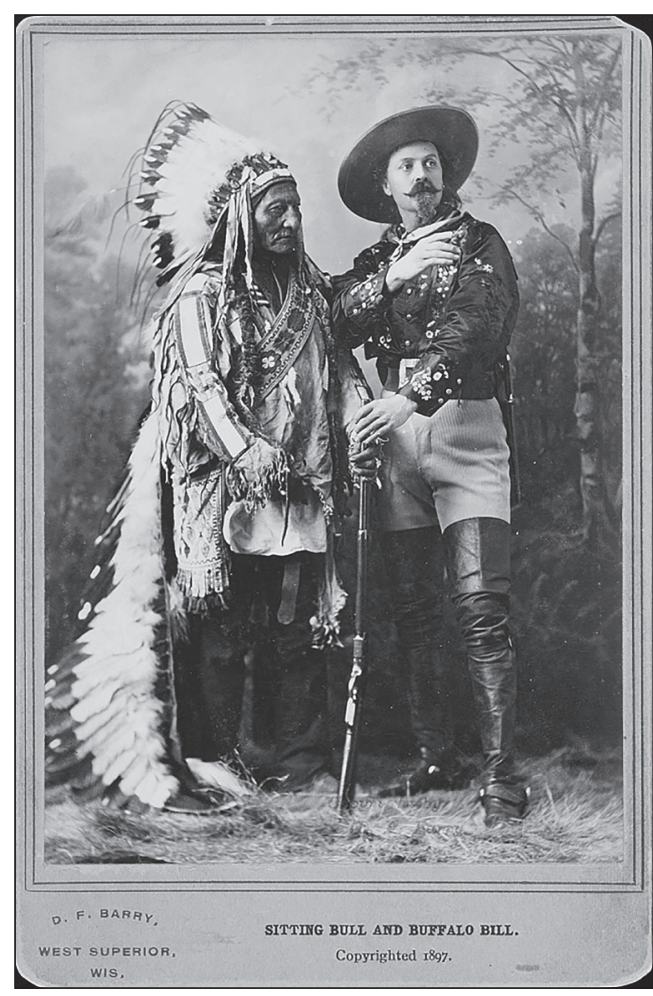

Figure 2. Buffalo Bill Cody and Sitting Bull, photo taken during Buffalo Bill's Wild West Show, August 1885, William Notman studios, Montreal, Library of Congress
William F. Cody, who lost his father at the age of eleven, provided for his mother and his five younger siblings as an ox-team driver during his childhood. As an adult, he was, among other things, a buffalo hunter, Indian fighter and army scout. Actually he continued his work as a scout for a couple of years, alternating it with his job as a performer and show manager. $\mathrm{He}$ was also a hero of dime novels. He first performed on a theater stage in 1872 in Chicago, in a drama entitled Scouts of the Prairie written by dime novel writer Edward Zane Carroll Judson who used the pseudonym Ned Buntine. Based on descriptions in the contemporary press, the drama must have been just awful, but Cody - playing himself, or, more precisely, playing a character with the name Buffalo Bill created by Buntine - was popular nonetheless. The critics praised his manly posture, handsomeness as well as his actions. One of his popular moves was when he saved a white girl from the hands of the Indians, shooting and carrying dead Indians offstage. This prompted him to form his own theatrical company, the Buffalo Bill Combination, that toured for the next decade, displaying stories of saving white maidens from savages. The project was so successful that it allowed Cody to change theater stage into something much bigger, namely that of the show arena later on (KASSON 2001:21-24; WARREN 2005:156).

In July of 1876, just a few weeks after the famous Little Bighorn battle, he cut his stage tour and went to Cheyenne, Wyoming, to serve as an army scout. The real reason was not exactly to fight the Indians and serve the nation. Custer's legend as a heroic victim of the Sioux, considered the last 'elements' of the wild world that needed to be tamed, was already being formed. In the war with the Sioux and Northern Cheyennes, Cody sensed a great drama that could potentially be 'repeated' on stage. Scouting for the army was to serve his personal needs, thus, promoting his stage career: by grasping a firmer connection with a now mythical general (WARREN 2003:51).

His military sojourn provided him with an opportunity to shoot and scalp the young Cheyenne warrior Yellow Hair at Warbonnet Creek, Nebraska. After claiming the warrior's scalp, he cried out: "The first scalp for Custer!" (HEDREN 2005:19-20). Later, he inserted the reenactment of the 'duel' into his shows, displaying as an advertisement 


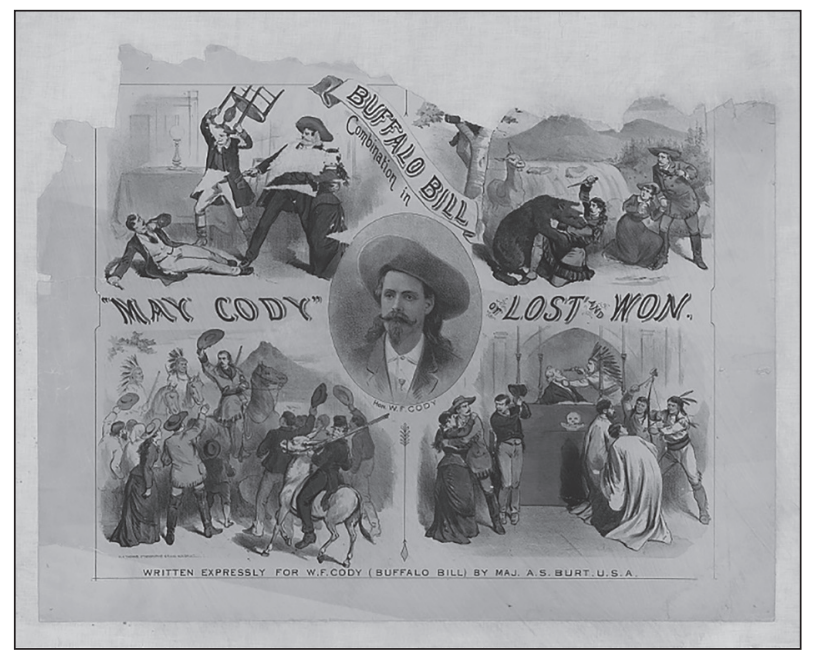

Figure 3. Buffalo Bill Combination in: "May Cody or lost and won", New York: H. A. Thomas Lithograph Studio, between 1890 and 1900, (Library of Congress, online resources https:// www.loc.gov/resource/ppmsca.54797/)

Yellow Hair's scalp, feather bonnet, and other trophies he had gathered after killing him (HEDREN 2005:21). In 1882, Buffalo Bill organized a buffalo hunt combined with a demonstration of horsemanship skills in Omaha, Nebraska. The show, which took place during the Fourth of July celebration, was a huge success. This inspired him to organize, together with an actor and theater manager Nate Salsbury, a larger outdoor show which started in 1883: "Buffalo Bill's Wild West, America's National Entertainment" (RYDELL Kroes 2013:30; Scarangella MCNENLY 2012:25). Buffalo Bill added exotic animals, men and women demonstrating various skills to the show. He continued to add enactments of 'historical' events, where he acted as an 'authentic' frontiersman (KASSON 2001:41).

In 1885, Cody added an Indian camp - where Cheyenne, Arapaho, Sioux, and Pawnee actors lived - to the show. The same year Sitting Bull (Fig. 2), who surrendered four years earlier, joined the show. The Hunkpapa chief, advertised as the 'killer of Custer', 5 contributed enormously to the show's popularity (SCARANGELLA MCNENLY 2012:25). ${ }^{6}$

Commencing during the winter of 1886 and continuing for several months, Cody initiated an indoor show at Madison Square Garden, New York, entitled The Drama of Civilization. It consisted of five parts - 'epochs'. The first 'epoch', called The Primeval Forest, presented Indians and animals living together before white man arrived. The Prairie, the second part, showed an emigrant train going forward despite numerous natural disasters, including a prairie fire. In the third epoch, Cattle Ranch, Buffalo Bill saved a pioneer family from attacking Indians. In the fourth, Mining Camp 'civilization' arrives in the form of the Pony Express and various cowboy tricks. In the final part, Custer's Last Stand, Buffalo Bill runs to save Custer but arrives too late (RYDELL - Kroes 2013:32) (Fig. 3).

During its first years, it was a spectacle aimed at providing an 'authentic' representation of western history, the conquest of the West and how its primitive inhabitants were "tamed"; sometimes adding a reenactment of the final part of the Little Bighorn, called

\footnotetext{
5 Which historically was not true: Although Sitting Bull directed the Sioux defense during the Little Bighorn battle, he did not enter in close contact with Custer.

6 Sitting Bull, after the season with Buffalo Bill's Wild West, returned to his Standing Rock Agency/ Reservation in North and South Dakota. He was killed by the Indian police in front of his cabin on December 15, 1890.
} 
Custer's Last Fight. It was not, however, the most recurrent theme of the spectacle, nor its climax as popular belief goes. Cody staged it for the first time at Madison Square Garden in 1887 - four years after he founded the show, and after he included it only sporadically until 1898, and never again in the United States, even though the show lasted another fifteen years (WARREN 2003). Cody's reputation as a sort of Custer's heir was already so well established thanks to his earlier stage efforts, journal articles, interviews (e.g. about his duel with Yellow Hair) and even his autobiography (CoDY 1879), as well as dime novels in which he was presented as Custer's add or even the sole white survivor of the Little Bighorn battle that probably repeating the scene of Custer's last fight was probably considered unnecessary and redundant by Cody and his partners (WARREN 2003:51-52, HutTon 1976:26-28, HedRen 2005:20-21).

However, he did display Custer's Last Stand during its European tours as is indicated by the advertising posters and the show's reviews in the local press (e.g. BOJANOwSKI 1906b:374). Exploiting Custer's myth was not risky in Europe where obviously it could not have been overplayed as it was in America. Naturally, more important than its ideological message was the drama and excitement the battle scene offered the audience.

\section{FROM THE WILD WEST TO THE CONGRESS OF ROUGH RIDERS OF THE WORLD: BUFFALO BILL'S INDIANS IN EUROPE}

Buffalo Bill's troupe toured Europe three times. In April of 1887 he brought his The Drama of Civilization, among other places, to the American Exhibition at Earl's Court in London, England, where he displayed a great Indian camp for tourists to go through, in order to watch Indian families playing and doing traditional activities (NAPIER 1999:385). They also put on a special, closed performance for Queen Victoria and then another one, this time at the Queen's request, for the royal family as well as the royalty of other European countries. With 97 Indians, mostly the Sioux, including performers and their families (Friesen 2017; Moses 1996:42), the show was "a smash hit in London", as the cultural historian Joy S. Kasson puts it (2001:75). According to Nate Salsbury, William Cody's business partner, two and a half million people watched Buffalo Bill's shows throughout six months of performances in London (KASSON 2001:77). The tour which, was soon to be known as the 'American National Spectacle', ended during the fall of 1888, with the shows in Birmingham and Manchester (RYDELL - Kroes 2013:107-109; NAPIER 1999:384-385).

The main destination of the second European tour, which started in May of 1889, was the Paris Universal Exposition where the show was performed for five months (KASSON 2001:82). Among the more than 10.000 spectators during the opening was the French president Sadi Carnot. Then the show moved to other parts of France, Spain, and Italy. In Rome, the performers were viewed by Pope Leo XIII. The show expanded during its tours in Germany from April to October 1890 (Dresden, Leipzig and Berlin, among many other cities) and again from April to May 1891. Then the show went to England to deliver yet another performance for Queen Victoria in 1892 (RYDELL - KROES 2013:109110). After returning to America, the show played next to the Columbian Exhibition in Chicago in 1893 and toured the United States for eight years.

During this second European tour, Cody and Nate Salsbury reshaped and enlarged the show, which for about a decade now had no longer been just a western history with 
Pony Express riders or Indians attacking the caravan of pioneers or a famous Deadwood coach. In 1891, while performing in Germany, they transformed the show into a display of the equestrian skills of peoples from different parts of the world. Native Americans (and cowboys) were joined by Syrian and Bedouin horsemen, Russian 'Cossacks', Argentine gauchos, Mexican vaqueros, as well as the British lancers regiment, German uhlans, French chasseurs, and ex-troopers of the U.S. Sixth Cavalry (Moses 1906:118-119; Roвa 2004:38). Custer's focus on the equestrian skills of different peoples of the world betrayed his fascination with horses - the fascination that he shared with the Native American tribes of the American Great Plains. Adding nomads from other parts of the world also meant a significant change of the spectacle's narration. From 1893 onwards, the show was called Buffalo Bill's Wild West and Congress of Rough Riders of the World, and rather than focusing on the conquest of the West, the show pretended to display a 'world history'; finding parallels between the conquest of the American and Eurasian frontiers and its primitive nomadic people, ${ }^{7}$ bedazzling 'centaurs' (that is why the horses, next to the Indians, were the most important 'props' of the show), the clash between the 'races', in Europe even more numerous than in America. Thus, Custer offered a stage version of a dominant then social Darwinism theory - a spectacular and amusing vision of the progress of the civilization of the world at the cost of the more primitive, but colorful and fascinating 'races' (WARREN 2003:61; 2005:331-332, 355-356).

The new performers of the show might have been actual nomads but the example of the 'Cossacks' advertised in the show's program proves that their precise ethnic origin was not necessarily the biggest concern of the inventors of the show. The promotional booklet of the Congress of the Rough Riders of the World described them as "belonging to the same branch of the great Cossack family, the Zaporogians, immortalized by Byron's 'Mazeppa'. Mazeppa was the hetman or chief of the Zaporogian community of the Cossacks of the Ukraine (...). On their lithe steppe horses, as fierce and active as themselves, they proved themselves more than worthy of their sires" (Buffalo Bill's Wild West Sketches \& PROGRAMME 1893:54). Indeed, they were not Cossacks but Gurians from western Georgia and they already performed in European circuses in the 1880s. They joined Buffalo Bill's show during his second European tour, and even travelled with the tour to America a year later (more on them and how they were recruited - MAKHARADZE 2015). The show's 'Beduins' were likely Berbers from the Rif Mountains.

Apart from ideological motivations, there was also a practical reason for the spectacle's revision. After the Sioux's Ghost Dance tragic winter of 1890 which included Sitting Bull's killing and the Wounded Knee massacre, ${ }^{8}$ thirty Lakotas, considered by the army to be the leaders of the movement who may still provoke tensions, were taken to Fort Sheridan in Chicago as prisoners. General Nelson Miles, who was in charge of concluding the Ghost Dance rebellion, and a personal friend of William Cody, purported that they join Cody's show in Europe. This way he hoped to lessen, if not extinguish, the unrest

\footnotetext{
Thus e.g. in Polish press it was advertised as "Brotherly union of the Wild West with the East" (Nowy Głos Przemyski 1906 no 30:3).

8 On December 29, 1890, the soldiers killed more than two hundred Lakotas, participants of the Ghost Dance movement. These Lakotas consisted of the Minneconjou band led by Chief Big Foot, and some of Sitting Bull's followers who found sanctuary among them. The Wounded Knee massacre marked the end of the wars with Indians in the United States.
} 
in the Sioux country. Also, he hoped the longer stay in Europe would assimilate them to the world of the white man, and that by observing "the extent, power and numbers of the white race", they would understand that further resistance is useless (Moses 1996:109110). Twenty-three prisoners agreed to go, and they joined another seventy-five Lakotas (of Oglala and Brulé bands) from the reservation - Buffalo Bill, again, convinced the authorities that letting these seventy-five go with him was in their interest because it guaranteed peace. However, employing Sioux was always difficult. First, because of their status as war prisoners. Second, some reformers and civilian authorities opposed the idea of hiring Indians in the Wild West spectacles which, according to them, would harm the process of their assimilation into white man's society. Thus, fearing that after their return to the United States, the Indians would be not allowed to perform with the show any longer, Cody and Salsbury, while in Germany, significantly changed the show (MosES 1996:109-119; WARREN 2005:382). Interestingly, while the Sioux who participated in later European tours were considered a threat to the peace, those who performed with Buffalo Bill by 1890 were loyal to the government and actively worked to diminish tensions among the Sioux who practiced the Ghost Dance (Moses 1996:109). ${ }^{9}$

Between 1887 and 1906, nearly one hundred Sioux performers took part in the Buffalo Bill's Wild West Show each year, many of whom came from the Pine Ridge Reservation (Oglalas). There were also Sioux from other groups and reservations.

According to Louis S. Warren, over the whole period of Cody's Wild West Show activity (1883-1916), "more than a thousand Indians chose to perform with his company" (WARREN 2005:359). There were, apart from the Lakotas, Comanches, Poncas, Pawnees, Arapahoes, Cherokees, Sacs and Foxes, and Kiowas (Scarangella MCnenly 2012:41).

There were many good reasons why Indians, and Lakotas especially, joined Wild West shows. Poverty and hunger prevailed at the Pine Ridge and other western Sioux reservations, which continue to be the poorest spots in the United States. In the aftermath of the Ghost Dance tensions and the Wounded Knee massacre, in times of even hunger in the reservation (the United States government did not always provide treaty provisions), alienation of the Sioux culture, allotment of their lands, the prospect of visiting big cities in the United States and in Europe while being paid for the travel and earning money must have been attractive. "We were raised on horseback; that is the way we had to work. These men furnished us the same work we were raised to; that is the reason we want to work for these kind of men", explained Black Heart, one of Buffalo Bill's Sioux actors (quoted in Moses 1996:103). Black Heart, while performing in Europe, did not forget to go sightseeing and, together with Cody and several other Indians, took a trip on a gondola in Venice along the Grand Canal.

9 In September of 1894 , Cody and some of his Indian actors were filmed by William Dickson in Thomas Edison's Black Maria Studio in West Orange, New Jersey. Dickson filmed four pictures lasting less than twenty seconds each: Buffalo Bill, Sioux Ghost Dance, Indian War Council, and Buffalo Dance (MussER 1991:50). These were the very first moving pictures with Native Americans - they were viewed at city arcades via peephole kinetoscopes. Celluloid Indians had to wait for their time (until 1908) when they turned out to be the solution for the narrative crisis in American films, which were losing favor with the French and Italian producers (Simmon 2003:9). 


\section{BUFFALO BILL AND HIS 'ROUGH RIDERS' IN POLISH CITIES: REACTIONS OF THE POLISH PRESS}

Buffalo Bill's Wild West show returned to Europe for the last time in December of 1902. It toured Great Britain, France, Italy, Austro-Hungary, ${ }^{10}$ Germany, Holland, and Belgium for four years (Moses 1996:189; FRIESEN - CHLADIUK 2017:36).

Like the previous European tour, the redone show Indians were just one group among 800 personnel that consisted of Arabs, Cossacks, gauchos, cowboys and cowgirls. As a show participant observed in his diary:

"Colonel Cody's exhibition is unique in many ways, and might justly be termed a polyglot school, no less than twelve distinct languages being spoken in the camp, viz.: Japanese, Russian, French, Arabic, Greek, Hungarian, German, Italian, Spanish, Holland, Flemish, Chinese, Sioux and English" (GRIFFIN 2010:604).

Indians, though, were still indispensable, because their presence guaranteed the fulfilment of the show's most important assurance, that of 'authenticity'. To them the show owned what was perceived as its unique American character. ${ }^{11}$ And, as in earlier versions of the show, Native Americans always had their village constructed in the vicinity of the show's arena in which they "lived exactly as they did many, many years ago" (FrIESEN - Chladiuk 2017:36). ${ }^{12}$

Unfortunately, the author, an American Charles Eldridge Griffin, a 'magic performer' and manager of the Buffalo Bill's show during its last European tournée, focused on his own touristic impressions of the places they visited rather than the shows' contents in various European cities, the show reception, or background of the performers. However, Polish language press from the territories belonging to the Austro-Hungarian Empire (Galicia and Austrian Silesia) at least partly fills empty spaces regarding the contents of the show and its reception, revealing interesting and unexpected contexts in which Buffalo Bill and Native Americans were used by the Polish authors.

Buffalo Bill's Wild West and Congress of Rough Riders of the World performed for sixteen days in the region of Galicia and Austrian Silesia, with shows in the following cities:

10 From December 1902 until October 1904, the show performed in numerous cities in England, Scotland and Wales. From April 1905 to December 1905, the show toured France. From March 1906 to May 15, it toured France again as well as Italy, and on May 16, 1906, it started its relatively brief route in Austro-Hungarian Empire, visiting cities such as Ljubljana and Maribor (in today's Slovenia), Zagreb (Croatia), Klagenfurt, Graz, Vienna (Austria), Budapest, Miskolc, Debrecen (Hungary), Kosice (Slovakia), Uzhhorod, Mukacheve, Kolomyia, Ternopil, Lviv (Ukraine), Kikinda, Zrenjanin (Serbia), Timişoara, Braşov, Sighişoara, Cluj-Napoca (Romania), Przemyśl, Rzeszów, Tarnów, Krakow, Bielsko-Biała, Cieszyn (Poland), Ostrava, Opava, Přerov, Brno and Jihlava (Czech Republic). Between August 15 and September 21, 1906, the show toured Germany, Luxemburg, France and Belgium. It sailed back to America from Antwerp, on September 22 (GrifFIN 2010:978-1080).

11 Along with Indians, some other crucial elements must be mentioned that indeed made Buffalo Bill's show unique and extremely popular in Europe: horses, American guns (Winchester and Colt), as well as perfect logistics and advertisement. See, for example RYDELL - KROESS 2013:113-115.

12 Apart from the spectacle performed in the main arena, there were many other sideshows which included, among others: performing rabbits, a snake charmer, a "moss haired lady" and tattooed man (FRIESEN - ChLADIUK 2017:36). 

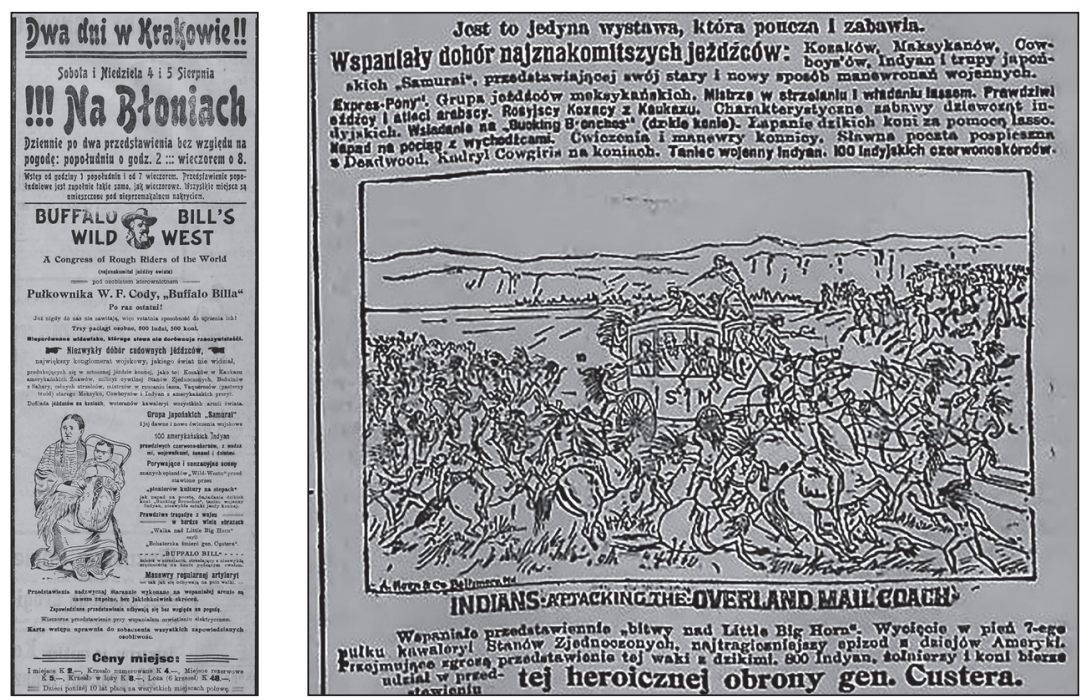

Figure 4. An advertisement in the local press of Buffalo Bill's Congress of Rough Riders of the World show in Rzeszów, Głos Narodu, 1906 no 348 (July 22):4

Figure 5. Fragment of an advert in the local press of Buffalo Bill's Congress of Rough Riders; World show in Cieszyn, Gwiazdka Cieszyńska, 1906 no 47 (July 28)

Kolomyia (July 23), Chernivtsi (July 24-25), Stanisławów (now Ivano-Frankivsk, July 26), Ternopil (July 27), Lviv (July 28-31), ${ }^{13}$ Przemyśl (August 1), Rzeszów (August 2), Tarnów (August 3), Krakow (August 4 and 5), Bielsko-Biała (August 6), Cieszyn (August 7), Ostrava (August 8), Opava (August 9), Přerov (August 10), Brno (August 11-12) and Jihlava (August 13). I will focus on the period of August 1-6 and discuss the shows played in Lviv (today's Ukraine) and the cities that currently belong to Poland. I will only occasionally refer to the press cover of the spectacles which took place in other cities.

Each show was very well publicized, with numerous posters hung on the buildings not only in the cities where it was going to be played but also in neighboring ones. Adverts were published in local newspapers many days in advance. The newspapers published also the programs, clearly provided by the tour managers. This is, except for some more detailed reviews in the same press, how we learn about the contents of the show. Judging by the information put on the press adverts, the shows in Polish cities seem to be very similar to one other.

Each day the show was performed twice. The newspaper adverts provided the following information: "A Congress of Rough Riders of the World (the best riders in the world) under the personal guidance of Colonel W.F. Cody, 'Buffalo Bill', is brought by three trains, contains 500 horses and 800 people. The exhibition, being the world international soldier conglomerate which has never been seen so far, contains: army veterans from England, North America, Russia, Arabia, Cuba ... It is the only exhibition that teaches and entertains. Grand choice of the best riders: Cossacks, Mexicans, Cowboys, Indians

13 These first five cities today are a part of the Ukraine. 
and bands of Japanese samurais" 14 or "Cossacks from Caucasus, American Zouaves, civilian militia from the United States, Bedouins from Sahara, sharpshooters, lasso throwing masters, Vaqueros (cattle shepherds) from old Mexico, Cowboys and Indians from American prairies". ${ }^{15}$

The program included:

"the group of Japanese 'Samurai' and their old and new military drills; 100 American Indians, real redskins, with chiefs, warriors, wives and children; thrilling and sensational scenes of the known episodes of the Wild West (presented by 'pioneers of the civilization' on the prairies), among them attack on the mail coach, mounting the wild horses 'Bucking Bronchos', Indian war dance, exceptional art of equestrianism; true tragedies of the wars in many pictures; Little Big Horn struggle or the heroic death of gen. Custer; Buffalo Bill, a great marksman shooting with incredible skill while sitting on the running horseback; maneuvers of the regular artillery exactly as they are conducted on the battlefield". ${ }^{16}$ (Figs 4-5)

For some authors, the perspective of arrival of Indian performers was a good enough reason to express great enthusiasm. The Indians did not arrive to a 'barren land'. European - including Polish audiences - had their own images of the native peoples of America, fashioned by popular literature (of famous authors such as Thomas Mayne Reid $^{17}$ and James Fenimore Cooper) as well photographs. Let us consider this quote from a weekly magazine from Rzeszów. The anonymous author announces the show that was to take place in that city:

"There is nothing more disheartening in the world than to see the disappearance of a human race which contains the noblest character traits. Indians of North America were once a happy and blossoming nation (...). The coming of the whites shook the foundations and the existence of this nation (...). Indians represent one of the most appealing points of the Colonel's Cody Wild-West show (...). These people demonstrate extreme patience, indifference, and calmness. Many their ancient customs and habits are interesting; they have preserved them from times immemorial, which is astonishing as today we observe the fast disappearance of all traditions among all the civilized nations." 18

14 Gwiazdka Cieszyńska, 1906 no 49:284. The 'Japanese samurais' were in fact Japanese soldiers whom Cody recruited during the Russo-Japanese War of 1905 (WARREN 2005:427).

15 Gtos Narodu, 1906 no 348:4.

16 Gtos Narodu, 1906 no 348:4.

17 Books by Mayne Reid, a $19^{\text {th }}$-century English author of popular books from the "Wild West", were already translated and published into Polish during the $1870 \mathrm{~s}$ and the $1880 \mathrm{~s}$, in the form of books and in serialized format in periodicals, e.g. by Wieczory Rodzinne, an illustrated magazine for children, printed in Warsaw.

18 Gtos Rzeszowski, 1906 no 29:2. All translations from the Polish press have been translated by Bartosz Hlebowicz. An Italian observer commented in a similar way during the same 1906 Buffalo Bill's Wild West tour: "Indians, the aborigines of America, are rapidly blending with the conquering white race, and their picturesque personalities are going to disappear completely from the world. In a few years they will not exist anymore, and civilization will dominate in the American continent end to end. Colonel Cody leads splendid types of these Indians who really represent the last of the Mohicans" (quoted in LotTINI 2012:189). 
One of the most common ideas about Native Americans has been that of the 'Vanishing Americans'. Americans have lamented the passing of the wilderness and Indians at least from the times of James Fenimore Cooper. A historian Francis Parkman wrote after Cooper's death: "Civilization has a destroying as well as a creating power. It is exterminating the buffalo and the Indian" (PARKMAN 1852:151-152). The famous $19^{\text {th }}$ century painter George Catlin and later the photographer Edward Curtis pretended to document with the brush and a camera 'the spirit of the past', and that of a 'vanishing race', ${ }^{19}$ before they finally demise. Curtis chose his The Vanishing Race photo as the opening one to his large photo project, presenting Native Americans whom he photographed for several decades in various parts of North America. Twenty volumes of his photos were published throughout the years 1907-1930. The photo caption reads: "The thought which this picture is meant to convey is that the Indians as a race, already shorn of their tribal strength and stripped of their primitive dress, are passing into the darkness of an unknown future (...)". Curtis also added that "the picture expresses so much of the thought that inspired the entire work" (CURTIS 1997:36), and that is why he chose it as the first one of the series. ${ }^{20}$

Of course, it cannot be stated with utter certainty that the aforementioned author knew the work of Curtis, but this is not the point. The similarity of their statements suggests a fascinating transoceanic travel of the idea which forever links Native Americans with the concept of "disappearing". The Native American were perceived as romantic, static, calm, and vanishing; as if vanishing was in their weaker nature or was a logical consequence of the world history. At the same time, the Polish author claims that Native Americans "preserved their interesting ancient customs and habits" which he contradicts with the rapid disappearance of traditions among "civilized nations". ${ }^{21}$

Thus, in the view of the author, Indians somehow live in some eternal ancient past, and at the same time their destination is doomed. We can propose that in the author's mind they are some cosmic creatures removed from time, always ready to teach us the things (e.g. holding on to the 'ancient traditions' would be such a thing) we have long forgotten. The same goes for their "patience, indifference, and calmness" - doubtlessly all these features were indispensable in order to remain ancient in the contemporary world. ${ }^{22}$

Not only Indians gained the admiration of the author:

"(...) a fantastic view when the Bedouins are galloping with the wind's speed in their white flowy clothes, waving their guns and brandishing their swords with such a speed that the spectators perceive only a shining wheel." ${ }^{23}$

19 The Spirit of the Past is the title of Curtis's 1906 photo presenting a few Crow Indians on horses, and The Vanishing Race (1904) is perhaps his most famous photo depicting Navaho Indians slowly riding towards the dark shadows of the canyon, away from the camera.

20 I am quoting Curtis from the new, one-volume edition of his photo encyclopedia (CURTIS 1997).

21 Gtos Rzeszowski, 1906 no 29:2.

22 A study of the Euroamerican myth of the 'vanishing Indians' and how it justified the conquest of America is offered by DipPIE 1991.

23 Gtos Rzeszowski, 1906 no 10:2. 
The author wrote his opinion ten days before the show came to his city ${ }^{24}$ (or to Galicia at all) which means he did not need to see the actual performers and performances to construct his opinions. After the show the same magazine published another comment, this time in a completely different tone. Its author, signed as Sigma, complained that from the place he lived - and it was about two kilometers from the show arena - even at 10pm, he:

"could hear a wild howling of various Apaches, Comanches and Sioux [that] gave me a headache. I thanked God that I had not gone. I saw those more or less true redskins when they were crossing the market square during the day. What they liked the most was to watch how our own liquid gold [feces] was being taken away from the toilets. They said such customs did not exist either in Mexico or in Paraguay" (Sigma 1906:3).

Then the author attempts to make a joke at the Indians' cost - another repetitive motif that I have encountered in the Polish press of the time. The Indians are good to laugh at and at the same time serve to make unrefined jokes about other things, for example local authorities. Sigma writes that he explained to the Indians that these were city authorities that arranged this 'smelly' show especially for them because they wanted to show them the best they had, and this was the best they had (Sigma 1906:3). Another journalist, from the newspaper in Cieszyn, described an encounter between the Indians and local people while the performers decided to visit the town before the spectacle. So many Cieszyn inhabitants surrounded them so that they stepped on their toes ${ }^{25}$ and one of the Indians cursed... in Czech. "It was explained to the astonished people that they probably dealt here with the descendants of that historical Czech who, while Columbus discovered America and entered it, jumped out of the bush and shouted: 'Pane Kolumbus, ja sem tady!' [in Czech: Mr. Columbus, I am here!] ${ }^{26}$ In the same article, the author offered another joke of similar quality. He writes: "It was thought that the Indians of Colonel Cody would catch with a lasso some puffer ${ }^{27}$ roast it alive on a spit and eat with an extraordinary appetite." Instead, as the author tells, they ate forty calves and a thousand eggs, and he laments: "Alas! These are, again, the results of civilization!"28

Some authors praised what we may refer to as the 'authenticity' of the show:

"Among the many attractions of the show I would like to indicate first of all extremely interesting and new kind of races. Some of them could not be done by any other similar show in the world... I mean the races between American mounted shepherd, so called cowboy, and cossack, arab, mexican, mounted shooter and an indian ${ }^{29} \ldots$ In the Wild West arena all the

24 The author wrote his piece on July 21, 1906. It was published a day after, and the spectacle in Rzeszów took place on August 2.

25 In a note: "Buffalo Bill has already started a show", published the morning before the first show in Krakow, a journalist informed that "valiant Indians punish resolutely those who too obtrusively stare at them" and that "on Florianska Street one redskin had slapped in the face two passersby that were too curious". (Gtos Narodu, 1906 no 373:4).

26 Dziennik Cieszyński, 1906 no 185:3.

27 The author uses the word 'dymel' which is not used in Polish anymore. Perhaps it meant a bison calf or a deer.

28 Dziennik Cieszyński, 1906 no 185:3.

29 For some reasons the author does not use capital letters. 
shows are marked by naturalness and truth. And this is only one of many extremely interesting points of Buffalo Bill's program."'30

This is how the event was announced in the next issue of the same newspaper:

\begin{abstract}
"There is no show that would be more entertaining ... This show is not only wonderful and thrilling, but also highly educative because with astonishing fidelity to detail it reproduces sensational scenes and terrific adventures from life of the wide western territories of the United States of that period when brave scouts and daring frontiersmen constantly had to deal with very dangerous and numerous enemies, humans and animals alike. Those times, which are fast disappearing from the memory of the young generations, in the history of America consist a chapter full of romantic episodes, characteristic for the epoch of growth and progress of the nation. In Buffalo Bill's 'Wild West' we see living examples of then pioneers of civilization; we see real Cowboys, true Indians." ${ }^{31}$
\end{abstract}

Here is one more example of the appreciation of the alleged historical accuracy of the show from the same journal:

\begin{abstract}
"One has to admit that Buffalo Bill fulfilled his promises, and very precisely. The American world from before not so remote times when the white Europeans with a loaded rifle had to conquer the land ... was presented in front of the spectators' eyes." ${ }^{32}$
\end{abstract}

Some of the Polish journalists highly praised both the entertaining and the educative qualities of the shows. For example, Stefan Bojanowski wrote enthusiastically about: the "perfect actors and members of a great American enterprise" (about cowboys saving German settlers from the attack of Indians), "agile, crazy, hellish and wild run" of the cowboy "flash-riderss [sic!]" and, again, the historical accuracy of the scenes in the show in his two-part report in a weekly Krakow magazine. In relating the presentation of the Little Bighorn battle, he writes: "One of the most spectacular was arrival of the colonel Cody on the battlefield. Historical fact. Colonel Cody ... unfortunately came too late, what he saw was only empty field, pools of dried blood, corpses and the ashes" (Bojanowski 1906b:374). According to Bojanowski, Colonel Cody himself, "the chief of all those strange colorful peoples and tribes", was the greatest part of the spectacle; demonstrating fascinating shooting skills and orchestrating the breathtaking parades of all of the colorful riders at the beginning and at the end of the show: "Colonel Cody, with grey hair in locks falling on his shoulders, most pretty figure of the beautiful Swede of the Thirty Years' War [!], is doubtlessly the finest and most interesting character of the whole circus personnel of the far 'Wild West'" (BOJANOwsKi 1906a:363-364).

Czas, a conservative newspaper from Krakow, offered the following description of the show that took place in a huge quadrangle formed of canvas tents (the article is merely signed with the initials: w. n.):

\footnotetext{
30 Gwiazdka Cieszyńska, 1906 no 48:276.

31 Gwiazdka Cieszyńska, 1906 no 47:271.

32 Gwiazdka Cieszyńska, 1906 no 51:292.
} 
"Introduction quite impressive. Instantly the riders, as if grown together with horses, enter the 'prairie' rapidly. Indians of several sibs. Their leaders carry vibrant names: Iron Hand, Flaming Tail, Lone Bear. We are in the world of Cooper, adjusted for the sake of money, in the world of Gerstäcker and Mayne Reid. Withered figures, painted with bright colors, their heads dressed with lots of feathers, which are drooping majestically. They look colorful. (...) Screech and cry of the redskins, loud rather than menacing, arouses emotions in my neighbors (...). New phalanges arrive, galloping and screaming. There are Rough Riders in grey clothes and with wide-brimmed hats, the Japanese in harmony with the Cossacks (...), Arabs, American and English cavalries. (...) At the end, with the Star-Spangled Banner, arrives the chief of all those tribes and peoples - Colonel Cody.

On a beautiful horse, in grey uniform, Buffalo Bill rides to the front of his troops and welcomes the audience by taking of his hat (...). All leave, Buffalo Bill leaves the last.

Now the show starts. After two or three circus performances we are really presented with the 'Wild West', theatrically sharpened, full of episodes, arranged with full knowledge of the circus perspective and with the full use of now ancient reality. Interesting things are happening on the prairie: an emigrant wagon train moves towards the Wild West, the Indians keep attacking, a horse thief is caught by lasso and lynched by the gun fire, an old stagecoach efficiently defends itself from the redskins, thanks to the help of cowboys who are escorting it (...) Cossacks and cowboys are making a horse-riding contest. Finally, in the midst of huge noise and smoke, 'the last battle of general Custer' takes place (...). Especially the cries of Lone Bear provoke terror among my young neighboring onlookers. All in Custer's unit are killed - the performance reaches its zenith" (w.N. 1906:1). (Fig. 6)

Then the author goes on to compare the shooting skills of Buffalo Bill and Johnny Baker (the second shooter of the show), claiming that Baker was better. However:

"Buffalo Bill [who shoots at eggshells] wins in the imagination of the spectators for two reasons: first, because he shoots while galloping on his horse [whereas Baker is shooting while lying on his back]; second, it is difficult not to think that what for Baker is only an art, for Buffalo Bill was an essence of life for decades. Eggshells were not the only thing those bullets used to reach. And imagination plays a huge role in those scenes from the 'Far West'. The spectators remember that this circus was once a life. Buffalo Bill invented a 'new thrill'." (w.N. 1906:1)

Leszek Mazan, a Polish journalist and a local historian from Krakow, made the following claim in 2013: "My grandfather saw this spectacle. He said the savage people performed on the arena. Many Krakovians thought the same" (Opryszek 2013). Polish authors appreciated not only the artistic, entertaining and educative contents of the shows but also the organization of the whole enterprise. Let us consider Bojanowski's description:

"The coaches were carried by 4 to 10 wonderful huge cold-blooded horses, guided by one mastercoachman, without a horsewhip. Two hours after the arrival of the first of them the huge circus tent was raised ... The public observed how American canvas city, in the evening and at night lit by the electric lamps, was raised on the Błonia [the Meadows - a historical large meadows in Krakow, situated close to the city center - B. H.]. It was built by several hundred men, working in silence, without rush and without disturbing each other's work." (BoJANOwsKI 1906a: 363) 


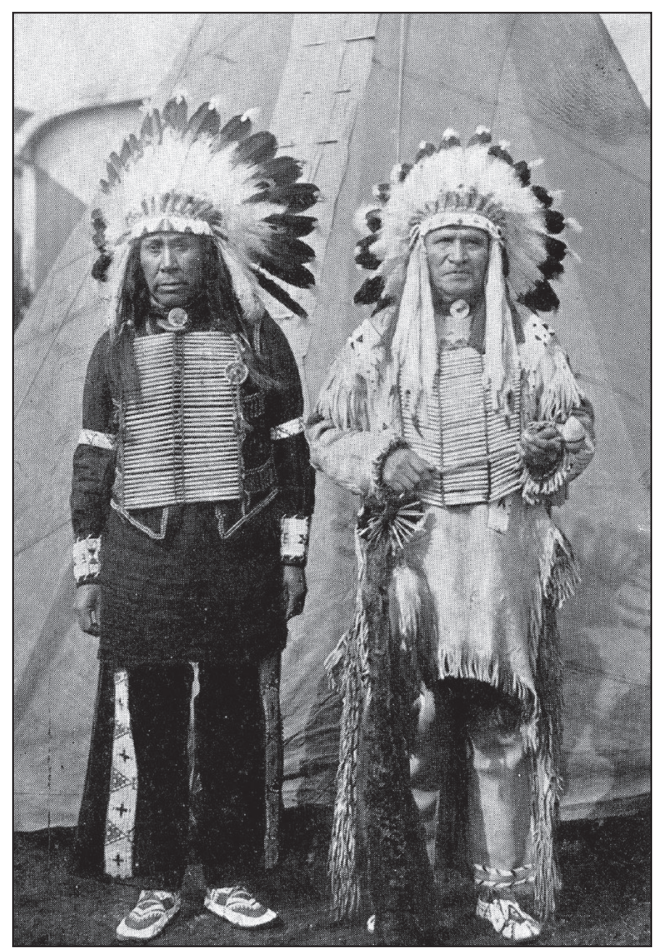

Figure 6. Sam Lone Bear and Mark Spider, veterans of the Buffalo Bill's Wild West; they were hired to perform at the Sarrasani Circus in Europe in 1928. Lone Bear toured with the Wild West shows from 1894 to 1935, including eight tours in Europe. The photo here is one of the souvenir postcards made for performers to sell (National Archives and Records Administration, Kansas City, Missouri)
The same author also noticed the very democratic character of the show which "earns profits from the pockets of all classes of the public, spurred on by the crazy American publicity which precedes each show of Buffalo Bill in the entire world". (BOJANOWSKI 1906a: 363)

The Dziennik Cieszyński reported on the "fabulous efficiency and discipline of the personnel" that could be observed while they were unloading the train wagons of the three trains that brought Buffalo Bill's troupe and helpers:

"Everything there works like in a precise machine. 300 people unload the railcars, and nobody commands them. Not even one word of command is given, you don't hear any calling. First they open the wagons with the horses. The men attach piers. Carthorses, already harnessed, leave the wagons without anybody leading them. Without anybody's help they form a long row, in pairs, one after the other (...). Twenty wagons were taken from wagon platforms and harnessed with several pairs of horses each in less than 45 minutes." 33

Another detailed account of the arrival of Cody's troupe in Krakow tells us about the reactions of the local inhabitants:

\begin{abstract}
“Our citizens, desiring extraordinary and so much publicized 'American sensations', got up really early. Already at $4 \mathrm{am}$ they were circling around Lubicz and Basztowa street, waiting for the daybreak and exotic figures (...). First big wagons with the tents, benches, and show requisites, pulled by three and often four pairs of heavy horses appeared to awaiting public on Lubicz Street already at $6 \mathrm{am}$. They were greeted with the signs of satisfaction, contrasting with the previous boredom, caused by the long waiting time. Then some disappointment could be seen on the faces, especially of those who were able to watch similar horses, wagons, and inside them thick planks for benches five years before when Krakow had hosted the circus Barnum et Beyley [sic! for Bailey]. They showed some more interest when some 'wonderfully colorful' Indians turned out, tall, broad-shouldered, with combed, luxuriant, ebony-colored hair and a complexion that provoked unfavorable remarks by the people who doubted its authenticity." ${ }^{34}$
\end{abstract}




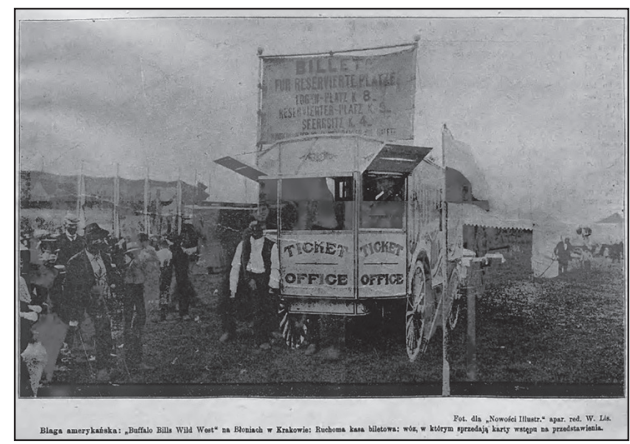

Figure 7. American sham Buffalo Bill's Wild West at Meadows (Błonia) of Krakow: moving ticket office: the wagon where they sell entry passes for the spectacle, photo W. Lis, Nowości Illustrowane, 1906 no 72.

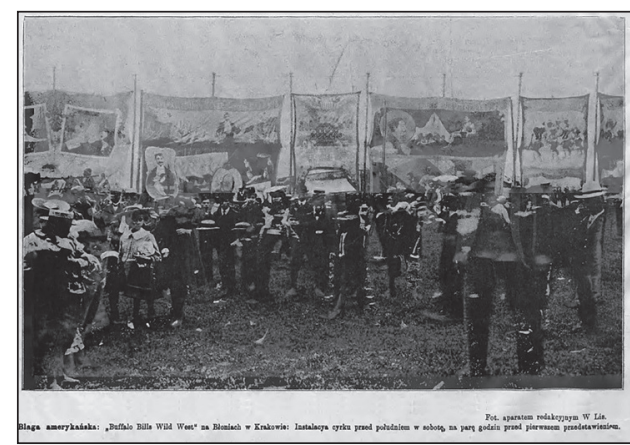

Figure 8. Buffalo Bill's Wild West at Meadows (Błonia) of Krakow: Installation of the circus on Saturday forenoon, a few hours before the first show; photo. W. Lis, Nowości Illustrowane, 1906 no 72 .

Then other small groups of 'copper race' and 'black race' performers came, one by one. "The people, indignant at their ugliness, did yell at them some jokes, not always quite esthetic." ${ }^{35}$ In the meantime the show crew worked on putting up a huge tent around the arena on the great meadows in Krakow (Błonia) where the whole procession was heading. This was the kitchen for 800 people. The journalist says that Cody and his people reportedly consumed $800 \mathrm{~kg}$ of meat a day, eating meat three times a day. ${ }^{36}$ (Figs. 7-8)

The local public could interact with the show's staff and performers in other ways as well. For instance, the morning after one of the shows in Krakow some local teenagers played a soccer match against some of Buffalo Bill's crew. According to a contemporary description, the guests' team was composed, among others, of a black goalkeeper, an Indian (Native American of course) man who was "faster than a horse", "a very smart Chinaman", "a Czech ventriloquist" and an Italian bicyclist whose specialty was to ride on the ladder (OPRYSZEK 2013).

Sometimes, the encounters that occurred outside the show arena were announced in press. For example, a newspaper from Lviv announced a "soccer wrestling match between the Buffalo Bill enterprise team and one of the local teams at the Society of Outdoor Games, at 5pm" 37 in the "Lviv calendar" section.

The nationalistic and anti-Semitic segments of the Polish press repeatedly published critical opinions on the show and its director. The authors either criticized the 'inauthentic' legend of William Cody and the actors performing in redface ${ }^{38}$ or in blackface, ${ }^{39}$ or simply

35 Czas, 1906 no 177:3.

36 Czas, 1906 no 59:3.

37 Stowo Polskie, 1906 no 339:1.

38 Stowo Polskie, 1906 no 339:2. Surely this was a case in the early years of Cody's career as a showman. In his autobiography he admitted, for example, that in his The Scouts of the Prairie he employed "between forty and fifty 'suppers' dressed as Indians" (CODY 1879:327). Also, John 'Captain Jack' Crawford, who like Cody, participated in the Great Sioux War, played Yellow Hair during Cody's stage show years (HeDren 2005:21).

39 Gwiazdka Cieszyńska, 1906 no 50:287. 

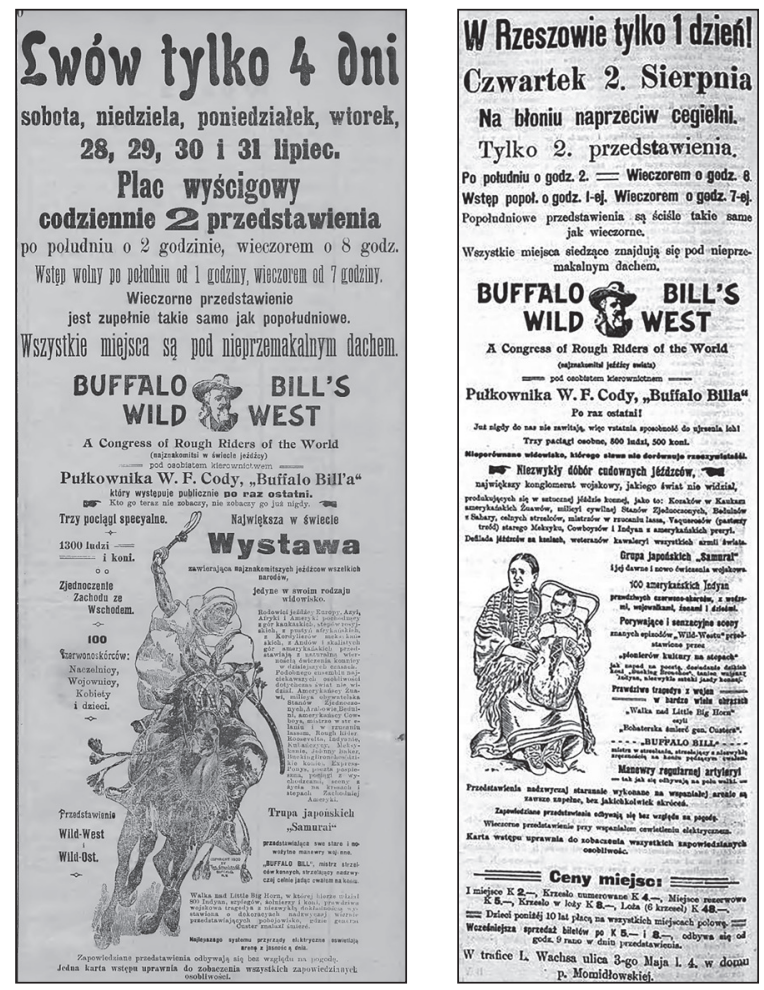

Figure 2. An Advertisement of Buffalo Bill's show in the local press from Lviv, Gazeta Lwowska, 1906 no 168 (July 25) Figure 10. An advertisement in the local press of Buffalo Bill's Congress of Rough Riders; World show in Rzeszów, Głos Rzeszowski, 1906 no 29 (August 5):4

that it was banal and boring. ${ }^{40}$ In one article, the artists were named: "Indians from Judenstadt with rooster feathers in their hair and the paint partly fading from their faces." ${ }^{41}$ The same newspaper in the following issue wrote that only "advertisement and organizations were perfect", and that the spectators watched "several dozen attenuated jades with savages on their backs". ${ }^{42}$

Another kind of criticism was directed towards the spectators who wasted their money on "useless spectacles" with "Indians and apes", on a "buffoonery run by a foreign fraudster"; for letting him carry away "several dozens of thousands of crowns", "thousands of guldens" or "millions of cents" that should have been used for other purposes, such as: Polish schools or houses and dormitories for Polish students or "some noble national purpose". ${ }^{43}$ "We do not care if Germans run there, but as for the Poles we feel sorry for this money which a farmer and anybody else needs in this difficult year." 44 The Echo Przemyskie
ckets and going to the show in order called spectators to stay at home instead of buying tickets and going to the show in order "to cheat Jewish chiselers". ${ }^{45}$ A newspaper from Lviv was furious that Buffalo Bill "is teaching us how to make publicity", ${ }^{46}$ railing against the fact that ten days before the show all the fences, free boards, walls and window panes in the city were covered with various posters advertising the show, written in broken Polish. ${ }^{47}$

\footnotetext{
40 Dziennik Cieszyński, 1906 no 173:3.

41 Echo Przemyskie, 1906 no 63:3.

42 Echo Przemyskie, 1906 no 61:3.

43 Quoted respectively from: Dziennik Cieszyński, 1907 no 107:3; Mieszczanin, 1906 no 16:6; Dziennik Cieszyński, 1906 no 185:3; Stowo Polskie, 1906 no 339:2; Goniec Jarosławski, 1906 no 25:4.

44 Diennik Cieszyński, 1906 no 180:3.

45 Echo Przemyskie, 1906 no 61:4.

46 Gazeta Narodowa, 1906:159.

47 For more about the criticism of Buffalo Bill's Wild West shows in patriotic or nationalistic Polish press - please see insightful article by Kamila BARANIECKA-OLSZEwSKA (2019).
} 
However, even the authors of negative relations about the show or those who attempted to discourage people from attending it very often admitted that the spectacles were very popular among the Poles. (Figs. 9-10)

\section{POLISH PRESS AT THE BEGINNING OF THE TWENTIETH CENTURY: THE INDIANS IN UNEXPECTED PLACES}

As we can see, Buffalo Bill and his 'Rough Riders' show sometimes became a pretext for social criticism as well as - quite unexpectedly - in the case of the nationalistically orientated press, for expressing anti-Semitic sentiments. Sometimes Buffalo Bill was no longer an American showman, but became a synonym for a Jew, a thief, and a fraud, as in an article in the Gazeta Przemyska published three years after Cody's show visited Przemyśl. The author of a rather primitive lampoon about some Jewish politician refers several times to his action and statements as "being 'Buffalo Bill":

\footnotetext{
"Isn't it 'to be Buffalo Bill' to write invented and totally deceitful things about the parliament, this way attempting to fool the listeners? Isn't it to be 'Buffalo Bill' to publish his speeches, not mentioning at all that the parliament hall was empty ... because nobody wanted to listen to his hackneyed cliché, said so many times already, isn't it a spoof? Isn't it to be 'Buffalo Bill' to write in his obscure rag that 'I went to the Minister of War, to the Minister of Treasure, that ...the watchmen will have their own palaces soon? (...) Yes! It is to be a true 'Buffalo Bill' designed for the stupidity of the narrow-minded crowd (...). This man, being at the same time (...) a Jew, a Pole and a Ruthenian, and in case of need he would as well become even a Chinese or a Tungus, promising - and promising only - the things, he is a worthless international 'Buffalo Bill' who would, if not for a fooled worker, vegetate as a small, week, unknown, but sassy provincial little lawyer." 48
}

Would Buffalo Bill ever think that he would become a synonym for a Jewish politician who beguiles Polish workers thus not allowing them to emancipate and take a proper place in society or among the nations, the place they deserve?

In another newspaper from Przemyśl, the author reflects upon the "uselessness" of the Austrian parliament whose members, while quarrelling, call each other 'apes'. Buffalo Bill's spectacle which was coming to that city, "will show more or less the same but for a lesser cost", concludes the author. ${ }^{49}$

'The Indians means wildness' - such an idea remained with one journalist even several years after the Buffalo Bill's show toured in Galicia. A short note, entitled Indians in Rzeszów, reported on the construction place where "the horses were whipped mercilessly, men were screaming shrilly". All this transported its author to the "region of the wild Indian tribes which were presented few years ago, in a very soft form, by a famous Buffalo Bill". ${ }^{50}$

\footnotetext{
48 Gazeta Przemyska, 1909 no 58:2.

49 Echo Przemyskie, 1906 no 61:3.

50 Głos Rzeszowski, 1912 no 26:5.
} 
Even an enthusiastic and open-minded commentator as Stefan Bojanowski seems to be, used Buffalo Bill's show as a pretext to ridicule German tourists who came from Silesia to watch the spectacle in Krakow. They "were fat with the beer, they screamed, and they wore such 'festival costumes' that Arabs, Indians, Cowboys and Cuban Cossacks, looking at them whispered discreetly among each other that these women, because of their coloration and gab, resembled the American parrots" (BOJANOwSKI 1906a:363). Or, describing the show's scene of saving German pioneers, he writes: "Liberated Swabians, not even saying 'thank you' to the Cowboys, picked up the interrupted migration, singing an arrogant song: "Mein Vaterland muss grösser sein"” (BOJANOWSKI 1906b:373).

The survey of the Polish press of the time when Buffalo Bill and his Congress of Rough Riders of the World, including the Sioux, came to this region of Europe in the summer of 1906, sheds light not only on the contents and the message of the show but also on to the internal political struggles, often quite brutal, and attitudes of the opinionmakers also towards the topics completely unrelated to the show and its performers. The Polish press of that period often put Indians in unexpected places (to borrow the title of the famous book of Philip Deloria, 2004) which paradoxically proves that 'Indianness' is one of the world's most durable myths, and the fewer Native Americans are around, the more durable it gets. Its vitality is also confirmed by the numerous relations and reactions, both positive and negative, in the Polish press and by the huge popularity of the shows among all classes of the public. Buffalo Bill's Native American (mostly Lakota $^{51}$ ) performers to many represented all Native Americans. This was very much like how Buffalo Bill's show was considered to represent and relay the entirety of American history. Similarly, for the nationalistic press in Polish cities at the time, a Jewish politician or trader stood for all Jews.

The 1902-1906 version of the Buffalo Bill's Wild West show was so huge and so impressive that other shows that attempted to perform in Europe in that period simply could not measure up (FriesEN - ChLADIUK 2017: 36-37). No doubt the presence of the Lakota and other Native American actors played a vital role in the success of the show. In its later stage, Buffalo Bill's project successfully combined a colonial narrative of the inevitable atrophy of the Wilderness ceding to Civilization and Progress with a sort of multiethnic and multicultural parade in which both a 'civilized cavalry' and 'exotic nomads' formed one army; one 'equestrian nation'. The spectators in Lviv, Rzeszów, Krakow and other Polish cities crowded the shows despite the numerous warnings and admonishments in the nationalistically-oriented press. This does not necessarily mean that they absorbed the American colonial message, more so that they simply enjoyed the perfectly organized, vivid shows - much like the Native American actors who rarely worried about the ideology behind the spectacle because they had more important reasons to participate in it.

51 Lakotas, as the horse-riding people from the Northern Plains, promised a larger audience than others (HABERLAND 1999). 


\section{REFERENCES CITED}

Baraniecka-Olszewska, Kamila

2020 Buffalo Bill and Patriotism. The Criticism of the Wild West Show in Polish Press in 1906. Journal of East Central Europe (forthcoming).

BojANOWSKI, Stefan

1906a Buffalo Bill na Błoniach krakowskich [Buffalo Bill at Krakow Błonie]. Tygodnik Rolniczy 33:363-364.

1906b Buffalo Bill na Błoniach krakowskich (Dokończenie) [Buffalo Bill at Krakow Błonie. Continuation]. Tygodnik Rolniczy 34:372-374.

BraY, Kingsley M.

2006 Crazy Horse. A Lakota Life. Norman: University of Oklahoma Press.

Buffalo Bill's Wild West Sketches \& PRogramme

1893 Buffalo Bill's Wild West and Congress of Rough Riders of the World. Historical Sketches \& Programme 1893. Chicago: The Blakely Printing Company.

Cody, William F.

1879 The Life of Hon. William F. Cody, Known as Buffalo Bill, the Famous Hunter, Scout and Guide: An Autobiography. Hartford: Frank E. Bliss.

CurTis, Edward S.

1997 [1907-1930] The North American Indian. The Complete Portfolios. Köln: Taschen.

Deloria, Philip

2004 Indians in Unexpected Places. Lawrence, KS: University Press of Kansas.

DiPPIE, Brian W.

1987 George A. Custer. In Hutton, Paul Andrew (ed.) Soldiers West. Biographies from the Military Frontier, 100-114. Lincoln - London: University of Nebraska Press.

1991 The Vanishing American. White Attitudes and U.S. Indian Policy. Lawrence, KS: University Press of Kansas.

Eco, Umberto

1994 How to Travel with a Salmon \& Other Essays, trans. from Italian by William Weaver. New York: Harcourt Brace and Company.

FrIESEN, Steve

2017 (July 24)Buffalo Bill \& His "Blood-Thirsty” Indians. https://truewestmagazine. com/buffalo-bill-his-blood-thirsty-indians/ (accessed December 14, 2018).

Friesen, Steve - Chladiuk, François

2017 Lakota Performers in Europe: Their Culture and the Artifacts They Left Behind. Norman: University of Oklahoma Press.

GRIFFIN, Charles Eldridge

2010 [1908] Four Years in Europe with Buffalo Bill. Edited and with an introduction by Chris Dixon. Lincolns-London: University of Nebraska Press (Kindle edition).

HABERLAND, Wolfgang

1999 Nine Bella Coolas in Germany. In FeEst, Christian F. (ed.) Indians and Europe: An Interdisciplinary Collection of Essays, 337-374. Lincoln - London: University of Nebraska Press. 
HEDREN, Paul L.

2005 The Contradictory Legacies of Buffalo Bill Cody's First Scalp for Custer. Montana: The Magazine of Western History 55(1):16-35.

HutTon, Paul Andrew

1976 From Little Bighorn to Little Big Man: The Changing Image of a Western Hero in Popular Culture. Western Historical Quarterly 77(1):19-45.

Kasson, Joy S.

2001 Buffalo Bill's Wild West: Celebrity, Memory, and Popular History. New York: Hill and Wang.

LotTINI, Irene

2012 When Buffalo Bill crossed the ocean: Native American scenes in early twentieth century European culture. European Journal of American Culture 31(3): 187-203.

MAKHARADZE, Irakli

2015 Georgian Trick Riders in American Wild West Shows, 1890s-1920s. Jefferson, North Carolina: McFarland \& Company.

Moses, L[ester]. G[eorge].

1996 Wild West Shows and the Images of American Indians, 1883-1933. Albuquerque: University of New Mexico Press.

Musser, Charles

1991 Before the Nickelodeon: Edwin S. Porter and the Edison Manufacturing Company. Berkeley: University of California Press.

NAPIER, Rita G.

1999 Across the Big Water: American Indians' Perceptions of Europe and Europeans, 1887-1906. In FEest, Christian F. (ed.) Indians and Europe: An Interdisciplinary Collection of Essays, 383-403. Lincoln - London: University of Nebraska Press.

OPRYSZEK, Szymon

2013 Jak Buffalo Bill na Błoniach grania w piłkę uczył [On How Buffalo Bill Gave Football Classes at Błonia Park] http://www.krakow.sport.pl/sportkrakow/1,115699,14101534,Jak_Buffalo_Bill_na_Bloniach_grania_w_pilke_ uczyl.html (accessed December 15, 2018).

PARKMAn, Francis

1852 The Works of James Fenimore Cooper. North American Review 74:147-161. RoBA, William 2004 German-Iowan Studies. Selected Essays. New York: Peter Lang.

Rydell, Robert W. - Kroes, Rob

2013 Buffalo Bill in Bologna: The Americanization of the World, 1869-1922. Chicago - London: The University of Chicago Press.

SCARANGella MCNEnLy, Linda

2012 Native Performers in Wild West Shows: From Buffalo Bill to Euro Disney. Norman: University of Oklahoma Press.

SigmA

1906b Z tygodnia [The Week]. Glos Rzeszowski 5 10(31):2. 
Simmon, Scott

2003 The Invention of the Western Film: A Cultural History of the Genre's First Half-Century. Cambridge: Cambridge University Press.

SмIтH, Andrew Brodie

2003 Shooting Cowboys and Indians: Silent Western Films, American Culture, and the Birth of Hollywood. Boulder: University Press of Colorado.

STANDING BEAR, Luther

1928 My People the Sioux. Boston - New York: Houghton Mifflin Company.

UTLEY, Robert

1993 The Lance and the Shield: The Life and Times of Sitting Bull. New York: Balantine Books.

WARREN, Louis S.

2003 Cody's Last Stand: Masculine Anxiety, the Custer Myth, and the Frontier of Domesticity in Buffalo Bill's Wild West. Western Historical Quarterly 34(1):49-69.

2005 Buffalo Bill's America: William Cody and the Wild West Show. New York: Alfred A. Knopf.

W.N.

1906 "Dziki Zachód" w Krakowie [The 'Wild West' in Krakow]. Czas [The Time] 59(178):1.

Bartosz Hlebowicz is an anthropologist, he received his Ph.D. in Humanities at the Jagiellonian University in Krakow (2004). He is an author of a monograph about the Oneida Indians of New York State and the Nanticoke Lenni-Lenape of New Jersey (Odnaleźć nasze prawdziwe ścieżki [To Find Our True Ways] Warsaw 2009). He translated and edited Lewis H. Morgan's The League of the Iroquois into Polish (2011). His research areas are: contemporary identity of the small Native American communities of the Eastern Seaboard of North America, representations of Native Americans in silent movies and in recently published Polish literature. In 2000-2010 he worked for Tawacin, a Polish journal on Native Americans. He is also a correspondent from Italy for a Polish Gazeta Wyborcza daily. He lives in Florence, Italy. E-mail: hlebar44@yahoo.com 